\title{
PELATIHAN STRATEGI PEMANFAATAN MODAL SOSIAL (SOCIAL CAPITAL) DALAM MENGHADAPI PANDEMI COVID-19
}

\section{Strategy Training For The Utilization Of Social Capital (Social Capital) In Facing The Covid-19 Pandemic}

\author{
Sulsalman Moita ${ }^{1}$, Amiruddin², Bahtiar ${ }^{1}$, Damsid $^{1}$, Iwan Patta ${ }^{3}$ \\ ${ }^{1}$ Program Studi Sosiologi Universitas Halu Oleo, ${ }^{2}$ Program Studi Pendidikan Biologi, \\ Universitas Halu Oleo, ${ }^{3}$ Program Studi IImu Kesejahteraan Sosial Universitas Halu Oleo
}

Kampus Bumi Tridharma Anduonohu Kendari, Jalan H.E.A Mokompit No.1 Kendari Sultra

${ }^{*}$ Alamat Korespondensi: moitasulsalman@yahoo.co.id

(Tanggal Submission: 3 Maret 2021, Tanggal Accepted : 5 April 2021)

\begin{abstract}
Keyword: Abstract :
Modal

Sosial,

Tongauna dan Mekar Sari merupakan dua kelurahan di Kecamatan Tongauna

Dampak, Kabupaten Konawe yang terdampak langsung Covid-19. Selain terdapat 3 angka kasus Pandemi, positif di kedua wilayah tersebut (Puskesmas Kecamatan Tongauna, 2020), dampak dan Covidlain yang dirasakan masyarakat adalah masalah ekonomi, sosial, dan psikologis. 19. Tujuan kegiatan pengabdian kepada masyarakat adalah: (1) Dipahaminya potensipotensi modal sosial sebagai input dalam menyelesaikan masalah akibat pandemi covid-19, dan (2) Dilaksanakannya strategi pemanfaatan modal sosial oleh masyarakat bersinergi dengan stakeholder dan pemerintah melalui penguatan potensi modal sosial pada level struktur, level koginitif, dan level relasional. Metode kegiatan adalah pelatihan dengan memfokuskan pada pendekatan sosialisasi dan forum group discussion. Hasil program pengabdian kepada masyarakat menunjukkan bahwa: (1) peserta pelatihan selain mampu memahami potensi-potensi modal sosial melalui bekerjanya elemen-elemen sikap saling percaya, relasi timbal balik, norma sosial, dan jaringan sosial; peserta juga mampu mempraktekan elemen-elemen tersebut baik dalam forum focus group discussion maupun dalam aktivitas kehidupan sehari-hari; dan (2) peserta pelatihan setelah memahami potensi modal sosial pada level kognitif, struktur, dan kognitif berkomitmen mengimplementasikannya melalui kerjasama warga dan stakeholder dalam berbagai kegiatan yang dilakukan sehingga dapat terbentuknya kelembagaan penanganan covid-19 berbasis organisasi kepemudaan.
\end{abstract}

Panduan sitasi / Citation guidance (APPA $7^{\text {th }}$ edition) :

Moita, S., Amiruddin, Bahtiar, Damsid, \& Patta, I. (2021). Pelatihan Strategi Pemanfaatan Modal Sosial (Social Capital) Dalam Menghadapi Pandemi Covid-19. Jurnal Abdi Insani Universitas Mataram, 8 (1), 54-64. http://doi.org/10.29303/abdiinsani.v8i1.375. 


\section{PENDAHULUAN}

\section{Analisis Situasi}

Kecamatan Tongauna merupakan salah satu wilayah kecamatan di Kabupaten Konawe yang terdampak secara langsung wabah Covid 19. Sejak wabah corona menjadi pandemi di Indonesia pada bulan Maret hingga Juli 2020 setelah memasuki era new normal, terdapat 4 kasus positif covid, yaitu 2 kasus di Kelurahan Sindang Mulya Sari, 1 kasus di Kelurahan Tongauna, dan 1 kasus di Kelurahan Mekar Sari; kemudian 5 kasus PDP masing-masing: 1 kasus di Desa Momea, 1 kasus di Kelurahan Mekar Sari, dan 3 kasus di Kelurahan Sindang Mulya Sari (Puskesmas Kecamatan Tongauna, 2020).

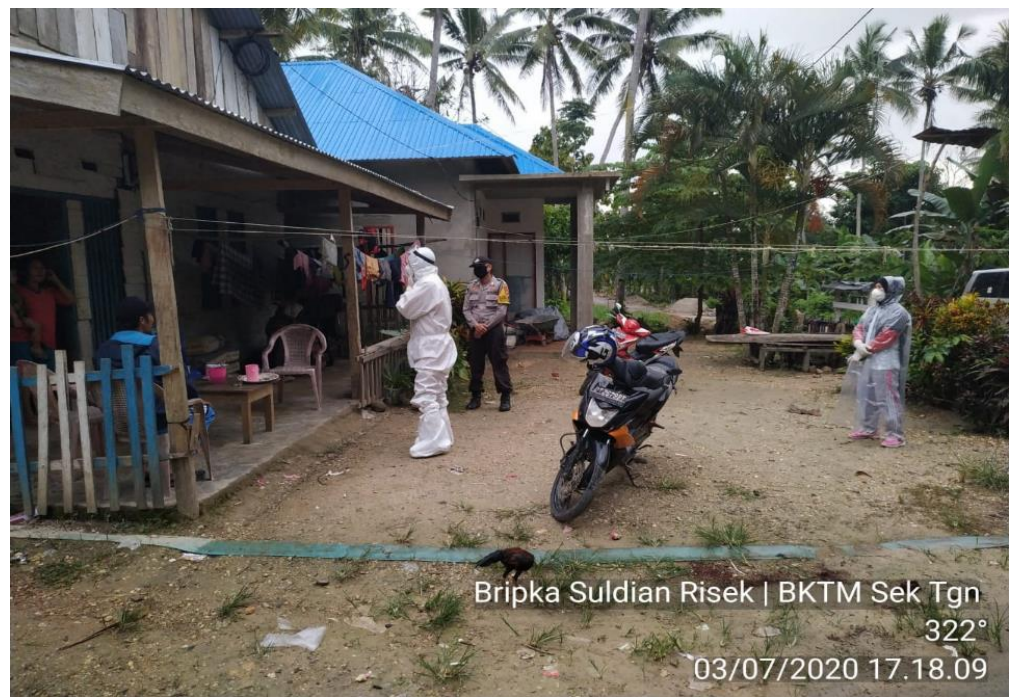

Gambar 1. Penjemputan Kasus Positif Covid 19 di Kel. Tongauna

Atas dasar kuantitas kasus tersebut, Pemerintah Kabupaten Konawe sebagai Satker penanganan Covid-19 di tingkat Kabupaten telah mengambil langkah-langkah strategis, antisipatif, dan tanggap darurat melalui sejumlah program dan kebijakan, antara lain: re-evaluasi dan pengalihan APBD 2020 sebesar 103 Milyar untuk penanganan virus corona, penutupan sementara semua lembaga pendidikan dari aktivitas pembelajaran; pengalihan fungsi kantor Diklat menjadi rujukan rawat inap dan rawat jalan korban covid; optimalisasi fungsi organisasi perangkat daerah untuk penanganan Covid-19 secara langsung melalui kegiatan seperti: pendataan warga calon penerima bantuan, penyemprotan cairan disinfektan, koordinasi dengan gugus tugas nasional dan provinsi, sosialisasi dan edukasi melalui media massa serta media elektronik, dan sebagainya.

Guna menindaklanjuti kebijakan nasional dan Pemda Kabupaten Konawe dalam penanganan Covid-19, maka wilayah kelurahan yang terpapar di Kecamatan Tongauna yaitu: Kelurahan Tongauna, Kelurahan Mekar Sari, dan Kelurahan Sindang Mulya Sari, telah diambil langkah-langkah strategis melalui peran kelembagaan kecamatan mulai dari Camat dan staf, Polsek Tongauna, Puskesmas Tongauna, para Lurah dan Kepala Desa se-Kecamatan Tongauna, organisasi lintas sektoral, stakeholder dan seluruh warga melalui gerakan bersama untuk mengeliminir dan membasmi covid19 seperti: penyemprotan cairan disinfektan pada kantor publik yang masih memberikan pelayanan dan rumah-rumah penduduk; pelarangan untuk tidak melakukan acara pesta dan seremony yang mengumpulkan banyak orang; pendataan warga miskin yang akan mendapatkan bantuan, sosialisasi $3 \mathrm{M}$ yaitu menggunkana masker, mencuci tangan, dan menjaga jarak; pembatasan aktivitas dirumah ibadah, dan sebagainya.

Selain gerakan bersama membasmi dan menghindari pandemi covid-19 yang diinisiasi oleh Pemerintah pada semua tingkatan, juga diperlukan peran serta masyarakat melalui penguatan nilai- 
nilai bersama yang bersumber dari modal sosial. Eksistensi social capital menjadi penting karena bersumber dan berakar dari nilai-nilai masyarakat untuk membangun kerjasama, jaringan, dan spirit tolong menolong. Modal sosial juga menjadi perekat di tengah krisis ekonomi dan sosial yang melanda masyarakat, terutama yang terdampak langsung covid-19.

Modal sosial merupakan kekuatan yang mampu membangun civil community yang dapat meningkatkan pembangunan partisipatif, dengan demikian basis modal sosial adalah trust, ideologi dan religi. Modal sosial dapat dicirikan dalam bentuk kerelaan individu untuk mengutamakan keputusan komunitas. Dampak dari kerelaan ini akan menumbuhkan interaksi kumulatif yang menghasilkan kinerja yang mengandung nilai sosial. Putnam (1993) menyatakan bahwa modal sosial sebagai karakteristik kehidupan sosial seperti jaringan kerja, norma, partisipasi, dan kepercayaan yang membentuk interaksi dan kerjasama yang saling menguntungkan untuk mencapai tujuan bersama. Fukuyama (1995) mendefinisikan modal sosial adalah serangkaian nilai dan norma informal yang dimiliki bersama di antara para anggota suatu kelompok yang memungkinkan terjadinya kerjasama. Modal sosial pada dimensi yang lebih luas yaitu segala sesuatu yang membuat masyarakat bersekutu untuk mencapai tujuan bersama, dan di dalamnya diikat nilai dan norma yang tumbuh dan dipatuhi (Gootaert, 2018). Bourdieu (1986) dan Kusumastuti (2016) menjelaskan bahwa modal sosial sebagai sumber daya yang dimiliki seseorang ataupun sekelompok orang dengan memanfaatkan jaringan, atau hubungan yang terlembaga dan ada saling mengakui antar anggota yang terlibat di dalamnya. Whitley dalam Regus (2020), menyatakan bahwa: modal sosial mendefinisikan hubungan interpersonal dan jaringan sosial yang memberi orang rasa identitas, tanggungjawab bersama, dan akuntabilitas kolektif. Selanjutnya Moita, dkk (2019), menyatakan bahwa eksistensi modal sosial dapat bersinergi dengan nilai-nilai kearifan lokal dalam memufuk kerjasama dan solidaritas sosial warga dalam menyelesaikan masalah-masalah sosial, ekonomi, dan budaya.

Dari bebeberapa konsep atau pengertian modal sosial tersebut di atas, maka sangat urgen dan penting bahwa nilai-nilai yang terkandung dalam elemen social capital tersebut sangat dibutuhkan untuk penanganan dampak pandemi virus corona. Misalnya melalui elemen resiprositas maka warga yang terdampak secara ekonomi akan memiliki kemampuan membantu kerabat yang tidak memiliki penghasilan akibat menurunnya pendapatan; kemudian melalui elemen social networking maka peran Pemerintah Kelurahan sangat dibutuhkan untuk mendata warga yang terdampak untuk diberikan bantuan sosial tunai (BST), pengadaan dan pembagian masker, penyemprotan cairan disinfektan; selanjutnya melalui elemen mutual trust, warga yang terdampak covid-19 akan diberikan bantuan kesehatan secara gratis serta pendampingan dari trauma guna tumbuhnya rasa percaya diri dan optimisme agar terbebas dari virus corona.

Berdasarkan pertimbangan di atas, maka Tim Program Kemitraan Masyarakat Internal LPPM Universitas Halu Oleo, mengusulkan kegiatan dengan tema "Pelatihan Strategi Pemanfaatan Modal Sosial dalam Mengahadapi Pandemi Covid-19 di Kelurahan Tongauna dan Kelurahan Mekar Sari Kecamatan Tongauna Kabupaten Konawe.

\section{Permasalahan Mitra}

Wabah Covid-19 yang melanda dunia termasuk Indonesia sampai saat ini belum ditemukan vaksin penanganannya. Selama kurang lebih 7 bulan sejak kasus pertama kali ditemukan di Indonesia pada tanggal 6 Maret 2020, telah mewabah di seluruh provinsi Indonesia dan hampir semua kabupaten/kota. Di Sulawesi Tenggara, tercatat hanya terdapat 2 kabupaten yang belum mencatatkan data penderita covid-19, sementara 15 kabupaten lainnya termasuk Kabupaten Konawe telah tercatat dengan jumlah penderita positif covid sebanyak 66 orang (Dinkes Kab. Konawe, 2020). 
Pandemi covid-19, tidak hanya berdampak bagi kesehatan masyarakat akan tetapi berdampak kompleks, mulai seperti ekonomi, sosial, psikologi dan politik. Di Kelurahan Tongauna dan Mekar Sari sebagai lokasi mitra, maka sejumlah indikator masalah yang teridentifikasi dan memerlukan program pemerintah, stakeholder termasuk penguatan elemen-elemen modal sosial, antara lain: a. Aspek kesehatan, masyarakat masih minim informasi dan pengetahuan terkait dengan protokol kesehatan dalam menghindari dampak pandemi covid-19; b. Aspek ekonomi, sebagian masyarakat golongan menengah ke bawah harus kehilangan lapangan kerja karena PHK, perumahan karyawan, terhambatnya usaha sektor informal, rendahnya pendapatan masyarakat, tingginya biaya hidup akibat inflasi, dan minimnya pemenuhan kebutuhan pokok; c. Dari aspek sosial, kebijakan work form home menyebabkan keluarga hanya berkumpul di rumah tanpa aktivitas yang produktif, sehingga berpotensi timbulnya disorganisasi keluarga, munculnya masalah-masalah sosial seperti pencurian, konsumsi miras, pengangguran, dan sebagainya; d. Dari aspek psikologis, menetap di rumah dalam jangka waktu yang cukup lama menyebabkan beban mental, emosi, stress, sehingga mempengaruhi kondisi fisik dan psikis keluarga.

Pelatihan strategi pemanfaatan modal sosial dalam menghadapi dampak pandemi Covid-19, dapat menjadi solusi selain program yang bersumber dari pemerintah dan stakeholder. Esensi modal sosial terdapat elemen-elemen seperti: sikap saling percaya, relasi timbal balik, nilai dan norma sosial, dan jaringan sosial, yang jika diakumulasi secara kolektif dapat mengeliminir bahkan menghilangkan dampak pandemi covid-19.

Perguruan tinggi dengan tanggung jawab Tri Dharma-nya, memiliki justifikasi yang memadai untuk memberikan solusi atas terjadinya pandemi Covid-19. Penanganan virus corona tidak hanya menjadi domain Pemerintah namun juga mendorong keterlibatan berbagai stakeholder, termasuk masyarakat. Berdasarkan hal tersebut, kami dari tim pelaksana Program Kemitraan Masyarakat Internal (PKMI) Universitas Halu Oleo Kendari mengusulkan kegiatan dengan tema "Pelatihan Strategi Pemanfaatan Modal Sosial dalam Mengahadapi Pandemi Covid-19 di Kelurahan Tongauna dan Kelurahan Mekar Sari Kecamatan Tongauna Kabupaten Konawe.

\section{Solusi dan target luaran}

Solusi yang ditawarkan dalam "Pelatihan Strategi Pemanfaatan Modal Sosial dalam Menghadapi Pandemi Covid-19" adalah memberikan pelatihan agar elemen-elemen modal sosial, sepert sikap saling percaya, relasi timbal balik, nilai dan norma sosial, serta jaringan sosial dapat dikuatkan dan dikaitkan dengan dimensi modal sosial pada level struktur, kognitif, dan relasional sehingga mampu menjadi solusi bagi masyarakat yang terdampak secara ekonomi, kesehatan, sosial, dan psikologi.

Program Kemitraan Masyarakat Internal dengan tema "Pelatihan Strategi Pemanfaatan Modal Sosial dalam Menghadapi Pandemi Covid-19", akan menghasilkan beberapa manfaat: a. Terbangunnya sikap saling percaya antara masyarakat, stakeholder dan aparatur pemerintah dalam menghadapi dan menanggulangi wabah virus corona, sehingga terjalin rasa kepedulian, tanggungjawab, komitmen, solidaritas guna membantu warga yang terdampak; $b$. Menguatnya relasi timbal balik antara warga dengan warga dan antara warga dengan pemerintah, melalui semangat tolong menolong membantu masyarakat yang terdampak, serta gotong royong dalam penataan kebersihan lingkungan dan penyemprotan cairan disinfektan; c. Mendorong terjalinnya ikatan jaringan sosial dalam mengeliminir dampak covid-19 melalui terbentuknya satgas penanganan di tingkat kelurahan, kerjasama dengan Puskesmas dalam penanganan medis, kerjasama dengan polsek Tongauna dalam menjaga ketentraman dan masuknya pendatang yang berpotensi membawa virus, kerjasama dengan Pemerintah Kecamatan melalui gerakan bersama penanganan covid-19 secara 
holistik dan terstruktur; d. Membantu Pemerintah Daerah dengan kemampuan anggaran, fasilitas, dan sumber daya manusia yang terbatas, sehingga penanganan pandemi covid 19 merupakan ikhtiar bersama.

\section{METODE KEGIATAN}

Berdasarkan hasil observasi dan identifikasi yang telah dilaksanakan pada calon lokasi Program Kemitraan Masyarakat Internal (PKMI), ditemukan bahwa Kelurahan Tongauna dan Kelurahan Mekar Sari merupakan wilayah yang berada pada zona kuning pandemi Covid-19. Kuantitas masyarakat yang terdampak langsung di atas, merupakan indikator bahwa wabah virus corona telah menulari masyarakat dari berbagai elemen. Wabah virus corona tidak hanya terkonsentrasi di kota akan tetapi juga telah masuk di wilayah kelurahan/pedesaan dengan status sosial masyarakat yang terdampak termasuk kelompok masyarakat menengah ke bawah.

Beberapa pendekatan atau metode yang ditawarkan dalam PKMI ini adalah: 1. Sosialisasi kegiatan Program Kemitraan Masyarakat Internal kepada mitra lokasi (Perangkat Kelurahan, petugas medis, babinsa, dan warga masyarakat); 2 . Survei lokasi terutama wilayah yang termasuk zona kuning dengan kasus covid-19, dengan tetap menjalankan protokol penanganan covid yang disyaratkan pemerintah; 3 . Pelaksanaan pelatihan melalui pemberian materi oleh tim pengabdian, tanya jawab dengan peserta, FGD dan praktek lapangan untuk mencari solusi bersama penanganan covid 19 dengan strategi pemanfaatan modal sosial, melalui pembagian masker, penyemprotan cairan disinfektan, dan pengecekan suhu badan; 4. Rekomendasi yang dihasilkan dalam pelatihan berupa komtimen bersama Pemerintah Kecamatan, Pemerintah Keluarahan dan warga ma syarakat mitra.

\section{HASIL DAN PEMBAHASAN}

\section{Program Kerja Program Kemitraan Masyarakat Internal (PKMI)}

Program Kerja PKMI di Kelurahan Tongauna dan Kelurahan Mekar Sari, memfokuskan pada 3 agenda yakni: a. Program yang fokus pada pemetaan elemen-elemen modal sosial dalam menghadapi pandemi Covid-19 antara lain: elemen mutual trus, resiprocity, social norms, dan social networking; b. Program kerja dalam bentuk FGD yang fokus pada tukar menukar informasi, pengetahuan, dan pengalaman dalam menghadapi masalah kesehatan keluarga dan masyarakat seperti wabah demam berdarah, diare, disentri; sehingga pengetahuan tersebut dapat diadopsi dalam menghadapi wabah virus corona; c. Program kerja dalam bentuk strategi problem solving melalui: pembentukan dan optimalisasi kinerja satgas penanganan Covid-19; sosialisasi dan edukasi protokol kesehatan; peningkatan kerjasama stakeholder seperti Pemerintah Kecamatan. Pemerintah Kelurahan, Puskesmas, Polsek, Dinas Cabang Pendidikan, dan Kantor Urusan Agama; serta mengoptimalkan sikap tolong menolong dan gotong royong warga.

Mengacu pada agenda program di atas, maka Program Kemitraan Masyarakat Internal bagi tim LPPM Universitas Halu Oleo adalah: melakukan Pelatihan Pemanfaatan Modal Sosial dalam Menghadapi Pandemi Covid-19", dengan fokus pada 3 indikator program sebagai berikut: a. Materi pelatihan tentang pemahaman dan urgensi modal sosial sebagai wahana pemersatu masyarakat serta pemahaman pemetaan elemen-elemen modal sosial yang dapat dimanfaatkan dalam menghadapi pandemi covid-19. Elemen-elemen modal sosial seperti sikap saling percaya, relasi timbal balik, nilai dan norma sosial, serta jaringan sosial; disinergikan atau dikaitkan dengan tipologi modal sosial pada level masyarakat (bridging social capital) dengan level pemerintahan 
dan lembaga (linking social capital); b. Materi pelatihan tentang pengenalan dan pengetahuan jenis-jenis penyakit menular termasuk virus corona dan dampaknya terhadap kesehatan masyarakat. Pemahaman jenis-jenis penyakit menular tersebut dapat diadopsi untuk diimplementasikan dalam menanggulangi wabah corona, misalnya: menjaga imunitas kesehatan keluarga, gotong royong dalam pembersihan lingkungan, edukasi pentingnya hidup sehat dan bersih, serta menjaga pola makan dengan gizi yang sempurna dan seimbang; c. Materi pelatihan terkait dengan membangun solidaritas, kerjasama, dan partisipasi masyarakat dalam menghadapi pandemi covid-19 yang disinergikan dengan eksistensi serta peran stakeholder dan pemerintah, melalui gerakan bersama penggunaan masker, penyemprotan cairan disinfektan, membantu warga yang terdampak, tidak menyelenggarakan acara yang menghadirkan banyak orang yang berpotensi penularan virus, dan gerakan untuk tidak keluar rumah jika tidak penting.

Refleksi dari tiga tema pelatihan tersebut, diimplementasikan dengan pemberian materi oleh narasumber yang memiliki kompetensi, kapasitas, dan pengalaman; sehingga implikasi dari pelatihan tersebut dapat bermuara dan berimplikasi munculnya metode dan strategi menghadapi dan menanggulangi wabah virus corona melalui pendekatan social capital. Pendekatan modal sosial, bukanlah pendekatan yang menyediakan dan menjanjikan penanggulangan wabah virus corona secara cepat dan tuntas, karena pendekatan ini lebih pada penguatan kapasitas masyarakat untuk turut memberikan peran dan kontribusi. Pemanfaatan modal sosial, lebih pada penguatan bentuk-bentuk modal sosial baik secara inklsuif (antar warga), ekslusif (bantuan pihak luar melalui lembaga-lembaga donor dan berbagai NGO/Ormas), maupun secara relasional (bantuan pihak pemerintah).

\section{Pelaksanaan Program Kemitraan Masyarakat Internal (PKMI)}

Pelaksanaan Program Kemitraan Masyarakat Internal mengacu pada program kerja yang telah dirumuskan pada tujuan berdasarkan kontrak dengan LPPM Universitas Halu Oleo. Sejumlah tahapan yang telah dilakukan oleh tim pelaksana antara lain:

\section{- Sosialisasi PKMI}

Sosialisasi dilakukan pada mitra program atau kelompok sasaran, dengan terlebih dahulu berkoordinasi dengan Lurah Tongauna pada tanggal 14 Oktober 2020 dan koordinasi dengan Lurah Mekar Sari pada tanggal 24 Oktober 2020. Hasil pertemuan selain membahas tujuan PKMI sebagai salah satu perwujudan Tri Dharma Perguruan Tinggi, tim pengabdian juga memperoleh gambaran tentang karaktersitik dan data penderita Covid, status OTG (orang tanpa gejala) dan ODP (orang dalam pemantauan) yang terjadi selama 6 bulan terakhir; data terkait programprogram penanggulangan wabah Covid-19; data jenis bantuan yang telah dialokasikan untuk warga yang layak menerima, data terkait jumlah penduduk/kondisi wilayah, dan sebagainya. Tim PKMI juga melakukan survai terkait kondisi lingkungan warga yang pernah terdampak langsung covid-19.

\section{- Penyediaan Sarana Program}

Guna mendukung kegiatan PKMI, tim pengabdian telah menyiapkan langkah-langkah pro aktif, konstruktif, dan inovatif agar kegiatan tersebut berjalan dengan baik dan sukses serta berimplikasi pada kehidupan warga atau kelompok sasaran.

Persiapan yang dilakukan sebelum pelaksanaan kegiatan pelatihan, antara lain: penyiapan materi, modul, gambar, alat peraga yang disampaikan pada sesi pelatihan. Sarana lain yang disiapkan adalah in-focus, atribut peserta, soundsystem, kursi, meja, tata dan dekorasi ruangan, foto copy materi, seminar kit, konsumsi, dokumentasi, dan sebagainya. Tim pengabdian juga 
menyiapkan fasilitas khusus pelatihan di masa pandemi Covid-19 antara lain: masker, handsanitizer, dan sabun cuci tangan, dan fasilitas tersebut digunakan atau dipraktekkan dalam kegiatan pelatihan.

\section{- Implementasi Program}

Implementasi Program Kemitraan Masyarakat Internal (PKMI), diawali dengan penyampaian/distribusi undangan kepada para peserta, yang terdiri dari: Lurah, para perangkat kelurahan, tokoh masyarakat, tokoh adat, tokoh agama, anggota karang taruna, remaja mesjid, kader posyandu, anggota PKK, warga yang terdampak langsung Covid-19, dan peserta lainnya. Puncak kegiatan dilaksanakan pada hari Kamis, tanggal 5 Nopember 2020, dengan mengambil tempat di Kantor Lurah Tongauna Kecamatan Tongauna Kabupaten Konawe. Kegiatan dengan tema "Pelatihan Pemanfaatan Modal Sosial (Social Capital) dalam Menghadapi Pandemi Covid19 " dihadiri oleh 30 orang peserta.

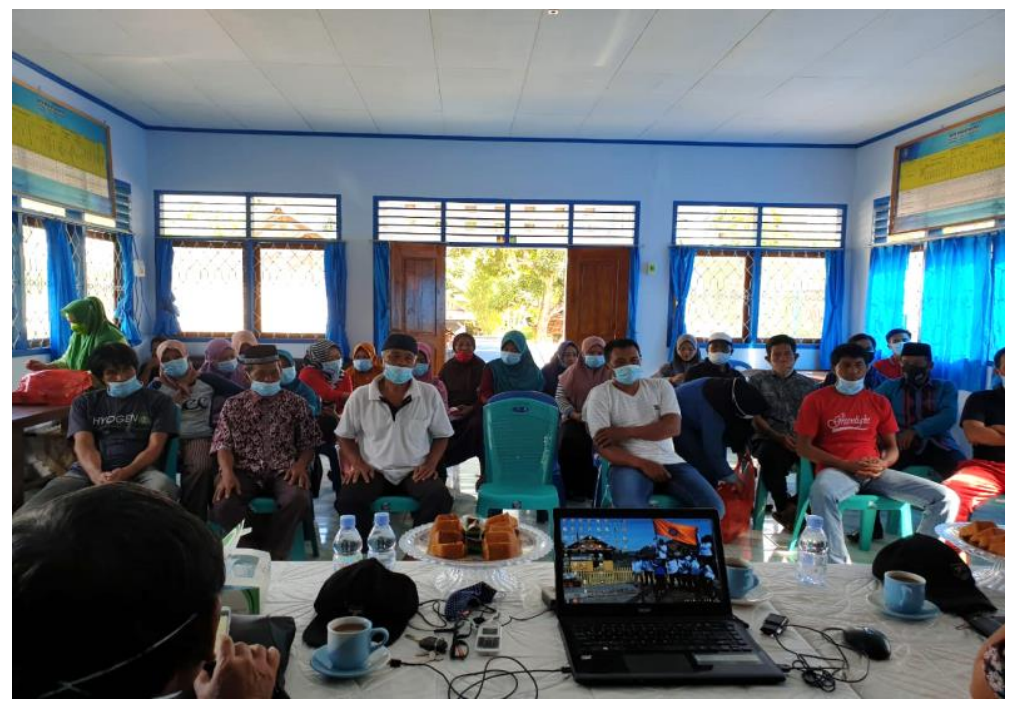

Gambar 2. Peserta Pelatihan

Kegiatan pelatihan dilaksanakan pada hari Kamis, tanggal 5 Nopember 2020 jam 08.00 Wita dibuka langsung oleh Lurah Tongauna (Hj. Dewi Biduri, SE, MM) dan turut memberikan sambutan Ketua Tim PKMI (Dr. Sulsalman Moita, M.Si).

Sesi selanjutnya adalah pemberian materi Pelatihan "Pemanfaatan Modal Sosial dalam Menghadapi Pandemi Covid-19, dengan nara sumber: 1. Dr. Sulsalman Moita, M.Si (Ketua Tim): "Identifikasi Potensi Elemen-Elemen Modal Sosial dalam Menghadapi Pandemi Covid-19"; 2. Dr. Amiruddin, M.Kes (Anggota Tim): "Prosedur Penanganan Pandemi Covid-19, Tinjauan dari Aspek Layanan Kesehatan Masyarakat"; 3. Iwan Pata, S.Sos, M.Si (anggota TIM): "Membangun Solidaritas, Kerjasama, dan Jaringan Sosial Warga, Stakeholder, dan Pemerintah dalam Menanggulangi Covid-19"; dan 4. Hj. Dewi Biduri, SE, MM (Lurah Tongauna): "Kesiapan Aparatur dan Warga Tongauna dalam Menghadapi Wabah Virus Corona. 


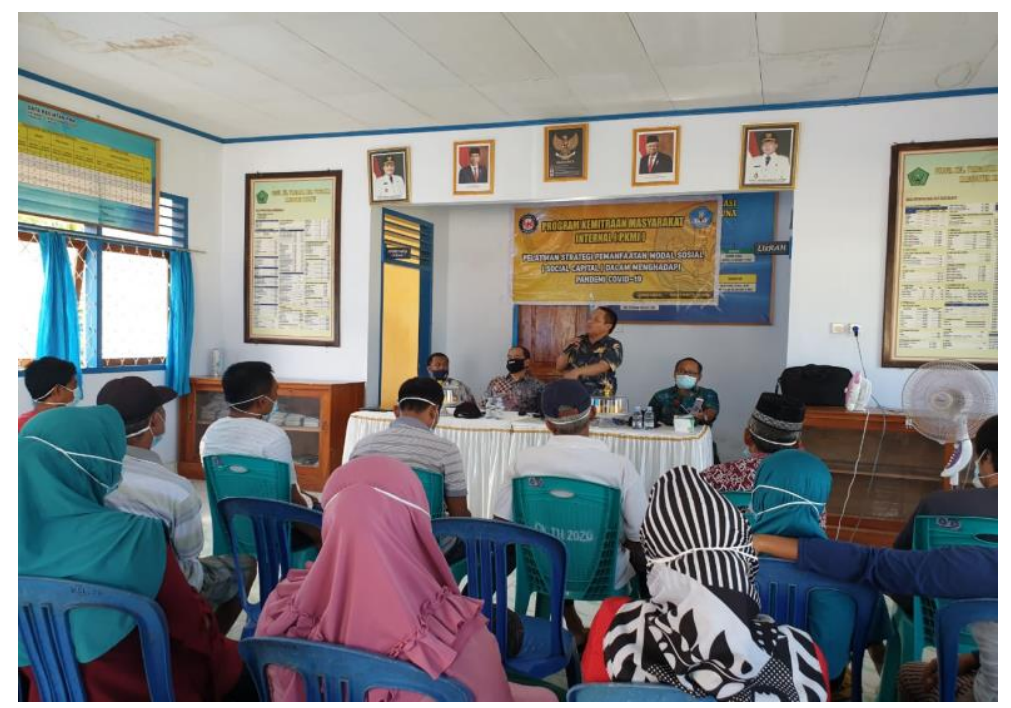

Gambar 3. Narasumber Pelatihan.

Pelatihan yang dilaksanakan selama kurang lebih 7 jam mendapat apresiasi dan respon positif dari peserta. Hal ini dapat dilihat pada banyaknya argumentasi dan pertanyaan peserta yang disampaikan terutama terkait dengan pemanfatan elemen-elemen modal sosial dalam menghadapi wabah virus corona. Beberapa pertanyaan yang diajukan peserta pelatihan antara lain:

- Pertanyaan peserta (Hasrim: tokoh pemuda) tentang minimnya pengetahuan warga dalam menghadapi pandemi Covid-19 yang terjadi secara tiba-tiba dan dianggap wabah menakutkan. la juga menanyakan masih minimnya bantuan pemerintah, termasuk masih ada sebagian warga miskin yang belum terdata sebagai penerima bantuan sosial tunai (BST).

Atas pertanyaan itu, maka jawaban Tim PKMI adalah: masyarakat harus memiliki kewaspadaan dini dalam menghadapi virus corona yang belum ada vaksin penanggulangannya. Kewaspadaan dalam menghadapi virus corona adalah sikap warga untuk berhati-hati untuk tidak melakukan hal-hal sebagai berikut: bepergian pada daerah kategori zona kuning dan zona merah penyebaran virus corona; kewaspadaan untuk selalu menggunakan masker dan menjaga jarak, kewaspadaan untuk selalu mencuci tangan pada air mengalir dengan menggunakan sabun, serta kewaspadaan untuk tidak menyelenggarakan dan menghadiri acara yang berpotensi menghadirkan banyak orang. Selanjutnya, terkait dengan data penerima bantuan, tim PKMI menjawab bahwa kebijakan itu adalah program Pemerintah yang akan mendata berdasarkan kondisi sosial ekonomi, data penerima, alokasi yang diberikan, dan kemampuan pemerintah.

- Pertanyaan dan saran (Idris Umar: tokoh adat), yang sangat mengapresiasi kehadiran tim pengabdian UHO dalam memberikan pelatihan dan penguatan kapasitas masyarakat. la memberi saran kepada Pemerintah Kelurahan Tongauna dan Kelurahan Mekar Sari untuk semakin waspada dan memperketat hadirnya pendatang di wilayah mereka, jangan sampai membawa virus corona; ia juga menyarankan untuk semakin mengaktifkan kegiatan-kegiatan bakti sosial dan gotong royong dalam kegiatan pembersihan lingkungan, pembersihan rumah ibadah, pembersihan posyandu, dan pembersihan drainase karena dampaknya bisa mengurangi potensi munculnya penyakit di lingkungan masyarakat. la juga mempertanyakan kepada tim, mengapa saat ini hubungan-hubungan sosial warga semakin renggang bahkan mengarah ke individualisme, padahal pengalamannya beberapa puluh tahun yang lalu warga sangat kompak, bekerjasama, tolong menolong dalam berbagai aktivitas sosial budaya. 
Atas pertanyaan dan saran tersebut, maka jawaban tim PKMI adalah sangat mengapresiasi komitmen tokoh adat untuk mempertahankan kebiasaan nenek moyang dari dulu yang masih mempertahankan relasi sosial dan hubungan-hubungan sosial (bersatu, berkumpul, dan bermufakat) untuk kegiatan-kegiatan sosial budaya, termasuk menjadi sarana pengendalian sosial terjadinya pelanggaran nilai dan norma masyarakat. Menurut tim PKMI, semangat relasi sosial, gotong royong, tolong menolong harus tetap dikedepankan termasuk dalam menghadapi pandemi Covid-19, misalnya memberi bantuan kerabat dan tetangga kita yang terdampak PHK atau kehilangan lapangan kerja sehingga tidak mampu memenuhi kebutuhan hidupnya; memberi sosialisasi kepada warga agar tidak menghindari kontak korban Covid-19 pasca sembuh, karena penyakit itu bukan virus kutukan, tetapi wabah yang bisa terdampak pada semua orang.

- Pertanyaan peserta (Marwiah: Ketua RW 3)) tentang bagaimana mendorong peran perempuan (ibu rumah tangga) di rumah yang terdampak Covid-19 seperti minimnya pemenuhan kebutuhan hidup karena pendapatan suami berkurang?

Atas pertanyaan tersebut, jawaban tim PKMI adalah anggota keluarga dalam rumah tangga harus sabar menghadapi cobaan ini, kemudian optimisme bahwa pandemi ini akan cepat berakhir sambil memperkuat komitmen anggota keluarga untuk melakukan aktivitas yang bermanfaat, seperti memanfaatkan pekarangan rumah untuk menanam sayur, komitmen untuk mengurangi pengeluaran seperti kebutuhan sekunder, membatasi konsumsi secara berlebihan dengan budaya hemat; kemudian tetap menjaga solidaritas dan kerjasama dengan warga sekitar guna mencari solusi bersama di masa pandemi covid-19.

Selain tantangan dan hambatan, apresiasi positif peserta juga nampak dari beberapa argumentasi dan rekomendasi dalam forum FGD, seperti:

- Pelatihan pemanfaatan modal sosial dalam menghadapi pandemi covid-19 menjadi wahana tukar menukar informasi dan pengalaman peserta: seperti pengalaman berdiam di rumah sebelum era new normal, pengalaman interaksi sosial warga selama pembatasan/pelarangan untuk melaksanakan acara pertemuan, pesta, dan seremony lainnya; pengalaman terkait solusi pemecahan masalah atas dampak ekonomi pandemi covid-19. Tukar menukar pengalaman melalui hasil diskusi akan melahirkan dan memaksimalkan ide-ide dan cara-cara efektif dan efisien dalam menghadapi pandemi Covid-19 melalui penguatan dan pemanfaatan elemenelemen modal sosial, seperti sikap saling percaya, relasi timbal balik, norma sosial. dan jaringan sosial.

- Materi pelatihan yang diberikan narasumber mendekatkan peserta dengan kebiasaan, sikap, dan tindakan dalam menghadapi pandemi Covid-19. Tim PKMI banyak menunjukkan gambargambar tentang bahaya virus corona, evidemi virus, cara penyebaran virus corona, dampak virus corona, dan cara menghadapi virus corona dengan pembagian dan penggunaan masker, praktek cuci tangam pada wadah yang sudah disediakan, dan praktek penggunaan handtaniziter.

\section{Monitoring dan Evaluasi}

Langkah selanjutnya setelah implementasi program adalah monitoring dan evaluasi. Monitoring dilakukan secara intensif dan terukur sejauhmana program-pelatihan dijalankan dengan baik sesuai dengan indikator yang telah disepakati sebelumnya.

Variabel untuk monitoring program parameternya adalah pada sesi pelaksanaan pelatihan, yakni sejauh mana kemampuan peserta dalam forum FGD memahami strategi dan pola 
pemanfaatan modal sosial (social capital) dalam menghadapi pandemi Covid-19 dengan pendekatan modal sosial melalui penguatan elemen: sikap saling percaya, relasi timbal balik, nilai dan norma, dan jaringan sosial.

\section{Peluncuran Hasil dan Produk}

Diseminasi kegiatan pengabdian kepada masyarakat adalah berbasis output atau luaran, dengan sejumlah indikator seperti model, strategi, inovasi, kebijakan, HAKI, artikel/jurnal, dan sebagainya. Secara umum hasil dari kegiatan pengabdian kepada masyarakat melalui PKM Pelatihan Pemanfaatan Modal Sosial dalam Menghadapi Pandemi Covid-19 adalah berupa dokumen laporan berupa kegiatan pelatihan yang memiliki implikasi positif bagi penerima program. Peserta pelatihan selain memiliki pengetahuan, keterampilan, kemampuan teknis, dan kewaspadaan dini menghadapi dampak pandemi Covid-19 melalui pendekatan modal sosial; juga dapat dijadikan rujukan untuk membangun dan merajut kembali rasa kebersamaan, rasa solidaritas sosial, kerjasama, gotong royong, semangat tolong menolong yang akhir-akhir ini mengalami degradasi akibat kemajuan zaman dan perkembangan ilmu pengetahuan dan teknologi.

\section{KESIMPULAN DAN SARAN}

\section{Kesimpulan}

Berdasarkan hasil pelaksanaan Program Kemitraan Masyarakat Internal (PKMI) dikemukakan kesimpulan sebagai berikut:

a. Pelatihan pemanfaatan modal sosial dalam menghadapi pandemi Covid-19 di Kelurahan Tongauna dan Kelurahan Mekar Sari Kecamatan Tongauna Kabupaten Konawe, menjadi alternatif pola penanggulangan berbasis kebijakan pemerintah yang belum maksimal akibat keterbatasan anggaran, fasilitas, dan sumber daya aparatur. Pendekatan modal sosial dengan menguatkan eksistensi elemen-elemen modal sosial melalui sikap saling percaya, relasi timbal balik, nilai dan norma sosial, serta jaringan sosial, dapat menjadi solusi alternatif dalam menghadapi pandemi Covid dari aspek kesehatan, ekonomi, sosial, dan psikologi;

b. Pelatihan pemanfaatan modal sosial menjadi starting point bagi seluruh stakeholder untuk merajut nilai kebersamaan, rasa persatuan, dan rasa persaudaraan bahwa pandemi Covid-19 harus ditanggulangi bersama berdasarkan nilai-nilai komunitas;

c. Pelaksanaan FGD menjadi wahana tukar menukar informasi dan pengalaman stakeholder dalam menghadapi pandemi Covid-19 sehingga dapat menghasilkan informasi, edukasi, dan pengetahuan terkait strategi menghadapi pandemi melalui aktivitas gotong royong, kerjasama, tolong menolong, empati sosial, saling percaya, dan sebagainya.

\section{Saran}

Berdasarkan kesimpulan tersebut, dikemukakan saran:

a. Pelatihan pemanfaatan modal sosial dalam menghadapi pandemi Covid-19 agar senantiasa intens dilakukan baik pemerintah, stakeholder maupun pihak lain termasuk Universitas Halu Oleo guna mensosialisasikan pengetahuan dan pengalaman dalam menghadapi wabah penyakit menular termasuk pandemi virus corona;

b. Diharapkan Pemerintah Kelurahan dapat mengalokasikan anggaran dana kelurahan untuk kegiatan-kegiatan fisik di bidang kesehatan seperti Perbaikan Posyandu, pondok bidan desa, pengadaan air bersih melalui program sumur bor, pengadaan jamban keluarga; termasuk 
kegiatan pelatihan di bidang layanan dasar kesehatan bermitra dengan Puskesmas, Dinas Kesehatan, dan Perguruan Tinggi;

c. Pemerintah Daerah Kabupaten Konawe diharapkan memaksimalkan upaya mengeliminir dan menghadapi pandemi Covid-19 dengan alokasi anggaran yang memadai terutama masyarakat yang terdampak langsung.

\section{UCAPAN TERIMA KASIH}

Terima kasih disampaikan kepada Lembaga Penelitian dan Pengabdian Kepada Masyarakat Universitas Halu Oleo, yang telah memberikan dukungan biaya dan bimbimgan teknis, sehingga kegiatan Program Kemitraan Masyarakat Internal (PKMI) dapat terlaksana dengan baik.

\section{DAFTAR PUSTAKA}

Bourdieu, P. (1986). The Form of Capital. In J. Richardson (Ed). Handbook of Theory and Research for Sociology Education. New York: Greenwood Press.

Fukuyama, F. (1995). Trust: The Social Virtue and The Creation of Properity. New York: Free Press.

Gootaert, C. (2018). Social Capital: The Missing Link ? Social Capital Initiative Working Paper No.3. World Bank.

Kusumastuti, A. (2016). Modal Sosial dan Mekanisme Adaptasi Masyarakat Pedesaan dalam Pengelolaan dan Pembangunan Infrastruktur. Masyarakat: Jurnal Sosiologi, Vol 20 (1).

Moita, S., Damsid., Kasim, S.S., \& Sarmadan. (2019). Model Penanggulangan Bencana Berbasis Sinergi Modal Sosial dan Nilai-Nilai Kearifan Lokal di Kabupaten Konawe Sultra. Prociding LWSA Conference Series 02.

Putnam, R. D. (1993). Making Democracy Work Civic Tradisitions in Modern Italy. New Jersey: Princeton University Press.

Regus, M. (2020). Pentingnya Revitalisasi Modal Sosial Paska Pandemi Covid-19. Jurnal Kependudukan Indonesia, Edisi Khusus Demografi dan Covid-19, Juli 2020. 